logy". While Childe was not an immediate intellectual prototype for it, it cannot be denied that his writings have helped prepare the way. Childe was ever interested in the search for regularities, "laws" in human cultural and social behaviour. Trigger makes the point, however, that Childe differed from the "new archaeologists" in seeing human behaviour as changing, not immutable. In this he was Marxist for he believed that behaviour changed as social context changed. For him the search for "laws" was a legitimate but not the primary objective of archaeology. The primary objective and the future of archeology lay, in his mind, with history - in the full context of social and cultural history. With this conviction, as Trigger says, he would have had little sympathy with archaeological examinations of "fragmentary" behaviour, behaviour out of context.

It is redundant or over-obvious to say that archaeology is "as large as life" but, indeed, it is; or at least it may legitimately encompass all aspects of human life in the past. Gordon Childe was very much aware of this. Those who view him as a special pleader or partisan adherent of limited theoretical views overlook the facts of his devotion to and masterly control of the data, the traditional data of form, time and space. What he did was to ask new questions and in attempting to answer these questions - all of which were of importance in understanding mankind's past - he made us aware of how much of the potential record remained to be discoverd. This was disturbing - and exciting - but it raised the discipline of archaeology to a whole new level of consciousness.

Gordon R. Willey is Bowditch Professor of Mexican and Central American Archaeology and Ethnology at Harvard University.

\section{Red bed diversity}

\section{J.R.L. Allen}

Continental Red Beds. Developments in Sedimentology, Vol. 29. By P. Turner. Pp. 562. (Elsevier Scientific: 1980.) Dfl.145, $\$ 70.75$.

THIS is an important and original book in which the author sets out to synthesize and review what we currently know of the nature, depositional environments and processes, and diagenesis of continental red beds. Continental red beds and the "red-bed problem" have fascinated sedimentary geologists for many years, and in the minds of some investigators have seemed of particular petrogenetic significance. Dr Turner's book illustrates the variety of the issues raised by investigation of continental red beds and shows that it is naive to conceive of a single red-bed problem. Its value is rather to illustrate the remarkable diversity of continental red beds, a diversity of diagenetic environments and history as much as of depositional environment.

There are four sections in the book. The first considers the tectonic and climatic setting of ancient red beds and leads to a preliminary assessment of the question of the origin of red coloration. A practical classification of red beds is advanced, based on depositional environment, colour characteristics and diagenesis. The second and longest section is a thorough review of the depositional processes and environments of modern continental sediments and of ancient reddened counterparts, such as the European Lower Permian, the Upper Coal Measures of South Wales, and the Old Red Sandstone of the British Isles. The third section is concerned with the diagenesis, mineralogy and geochemistry of continental red beds. The fourth comprises two chapters, of which the first is a general account of the magnetization of continental red beds, and the second a study of magnetization case-histories (Proterozoic basins of western Canada,
Late Precambrian of Scotland, Moenkopi Formation of western USA, late Cenozoic red beds of Baja California). These clearly illustrate the complex controls on the magnetization histories of continental red beds and the difficulties of interpreting palaeomagnetic data, even when a wide variety of supporting field, petrographic and geochemical information is available.

Dr Turner's book is a carefully researched and well-written account of the sedimentology of continental red beds, the author moving confidently from largescale phenomena to problems on the smallest of scales. The book was prepared from camera-ready typescript (there are a few small errors) and is well-illustrated by line drawings and photographs. There is an extensive and up to date list of references. The book is expensive but no sedimentologist concerned with continental sediments can afford to neglect it.

J.R.L. Allen is Professor of Geology at the University of Reading. His research interests include the sedimentology of the Old Red Sandstone (a series of continental red beds of Devonian age) in southern Britain.

\title{
Introduction to liposome research
}

\section{Timothy D. Heath}

Liposomes in Biological Systems. Edited by G. Gregoriadis and A. C. Allison. Pp. 424. (Wiley: 1980.) $£ 23, \$ 69$.

Liposomes in Biological Systems is the first book to be devoted completely to this aspect of liposomes. Its publication reflects the considerable expansion which has recently occurred in liposome research.

The book begins with a contribution by A.D. Bangham who traces the history of liposomes as he and others first characterized them, and their subsequent use by biologists. Following this, Dr Gregoriadis summarizes the potential applications of liposomes as drug carriers, and expresses his hopes for the future.

In the subsequent chapters various specialist authors concentrate largely on their own contributions to the field. J.H. Fendler describes the various factors concerned with encapsulation of drugs. G. Poste gives a critical review of liposomecell interactions, which will enlighten those who may still believe the predominant mode of vesicle-cell interaction to be fusion. This area of liposome research in particular has been the subject of much recent reconsideration. Several chapters are devoted mainly to the in vivo fate of liposomes and their contents, including the uptake of enzyme-bearing liposomes by G. Weissmann and M. Finkelstein. G. Scherphof et al. have described their efforts to elucidate the interaction of liposomes with serum components, and $\mathrm{H}$. Kimelberg discusses his work on the in vivo fate of encapsulated methotrexate. I. H. Shaw and J. T. Dingle describe the interarticular injection of steroidcontaining liposomes which is indeed one of the most promising applications of liposomes so far developed. (It would also have been appropriate had this volume included a chapter on the work of C. D. V. Black, R. R. C. New and C. R. Alving on the use of liposome-encapsulated antimonials in the treatment of visceral Leishmania, which clearly may be one of the first successful therapeutic applications of liposomes.) The final specialist chapter, by G. M. K. Humphries, covers the use of liposomes for studying in vitro immune reactions, which will undoubtedly become a major area of liposome research.

The contents of this volume are very similar to those of Vol. 308 of the Annals of the New York Academy of Sciences (1978), and most of the contributions appear to have been written between 1976 and 1978 . The delay in publication is unfortunate, although Dr Gregoriadis has added a short chapter which summarizes much of the more recent literature.

In conclusion, this volume will provide a useful introduction for those unfamiliar with the field.

Timothy $D$. Heath is a research fellow at the Cancer Research Institute, University of California, San Francisco. 